\title{
Науково-освітня школа «Проектування і конструювання ефективної високоресурсної авіаційної техніки» кафедри проектування літаків і вертольотів
}

\author{
Національний аерокосмічний університет ім. М. Є. Жуковського «ХАl»
}

\begin{abstract}
Розвиток науково-освітньої школи (НШ) «Проектування і конструювання ефективної високоресурсної авіаційної техніки» на кафедрі проектування літаків і вертольотів у Національному аерокосмічному університеті ім. М. Є. Жуковського «Харківський авіаційний інститут» почався з перших років існування кафедри 103 під керівництвом професора Й. Г. Немана. Саме він започаткував принцип «включати до навчального процесу реальне проектування», що привело до створення першого в Україні студентського конструкторського бюро (СКБ XАІ). Це підвищує інтерес до навчання та спонукає підвищувати відповідальність за ухвалення рішення.

Традиція відповідального і творчого ставлення до науково-освітнього процесу була продовжена і при наступних керівниках НШ: доцента П. В. Дибського, доцента Ф. Г. Ясинського, Генерального конструктора О. К. Антонова, професора Л. О. Малашенка, професора В. І. Рябкова, професор О. Г. Гребенікова.

Фахівці кафедри виконують програми спільних науково-дослідних робіт із ДП «Антонов» та АТ «Мотор Січ» та підтримують міжнародні зв'язки з фахівцями США, Росії, Німеччини, Чехії, Канади, Японії, Ірану, Індії, Китаю і Мексики.

При вирішенні завдань розвитку авіаційної промисловості важлива роль відводиться моделюванню авіаційної техніки за допомогою комп'ютерних інтегрованих систем, застосування яких істотно скорочує витрати і терміни створення літаків, підвищує якість і конкурентоспроможність авіаційних проектів.

За результатами науково-дослідної роботи викладачами кафедри отримано авторські свідоцтва на винаходи та патенти, опубліковано фундаментальні наукові і навчальні видання.
\end{abstract}

Результати наукових досліджень впроваджені на авіаційних підприємствах України та країн СНГ, а також у навчальному процесі авіаційного університету. Діяльність кафедри відповідає основним критеріям і вимогам положень про наукову школу.

Ключові слова: науково-освітня школа; проектування; авіаційна техніка; комп'ютерні інтегровані системи.

Наукова школа є невід`ємною основою розвитку наукового пізнання та розвитку навчально-виховного процесу.

Розвиток наукової школи (НШ) «Проектування і конструювання ефективної високоресурсної авіаційної техніки» на кафедрі проектування літаків і вертольотів у Національному аерокосмічному університеті ім. М. $€$. Жуковського «Харківський авіаційний інститут» починається з перших років існування кафедри 103. Послідовно керівниками наукової школи та її окремих напрямків були завідувачі кафедри та ведучі науково-педагогічні працівники.

Професор Й. Г. Неман - кавалер ордена Червоної Зірки, завідувач кафедри літакобудування у 1931-1936, 1944-1952 рр.

Е. І. Майоранов - завідувач кафедри літакобудування у травні 1939 р. травні 1942 р.

Г. М. Воробйов - завідувач кафедри літакобудування у січні 1943 р. березні 1944 p. 

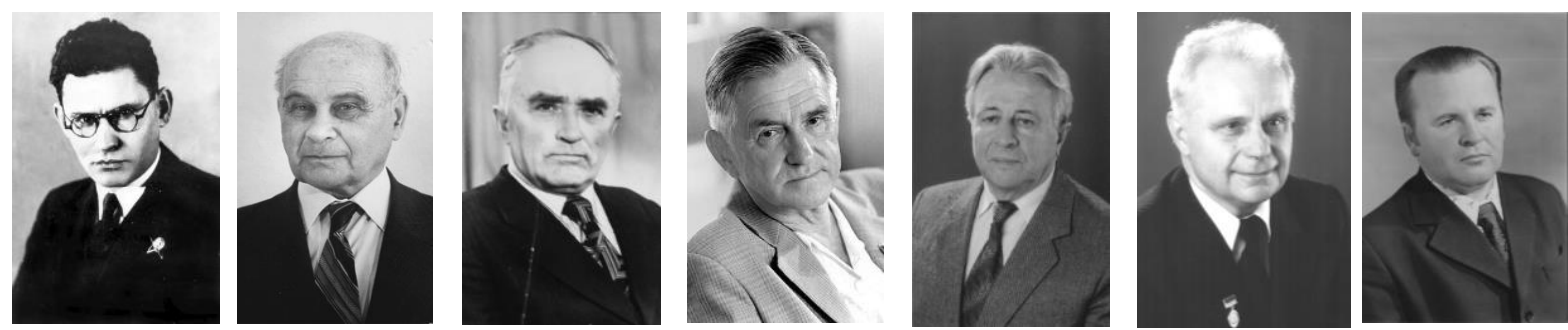

Рис. 1. Завідувачі кафедри і керівники наукової школи різних років

Зліва направо: Й. Г. Неман; П. В. Дибський; Ф. Г. Ясинський; О. К. Антонов; Л. О. Малашенко; В. І. Рябков; О. Г. Гребеніков

Доцент П. В. Дибський - кавалер ордена «Знак пошани», завідувач кафедри конструкцій літальних апаратів у 1952-1965 рр.

Доцент Ф. Г. Ясинський - завідувач кафедри конструкцій літальних апаратів у 1965-1977 рр.

Генеральний конструктор О. К. Антонов - Герой Соціалістичної Праці, професор, доктор технічних наук, академік НАН України, завідувач кафедри конструкцій літаків у 1977-1984 рр.

Генеральний конструктор П. В. Балабуєв - Герой Соціалістичної Праці, Герой України, профресор, доктор технічних наук - з 1988 року очолював фрілію кафедри проектування літаків XАІ на АНТК ім. О. К. Антонова.

Головний інженер ДП «Антонов» С. А. Бичков - профресор, доктор технічних наук, заслужений працівник промисловості України, відповідальний організатор навчальної, наукової та виховної роботи серед студентів і аспірантів на ДП «Антонов».

Профресор, доктор технічних наук Л. О. Малашенко - заслужений працівник вищої школи України, завідувач кафедри конструкцій літаків у 1984 1990 рp.

Профресор, доктор технічних наук В. І. Рябков - завідувач кафедри проектування літаків і вертольотів у 1990-2007 рр., проректор XAІ у 1987-1999 рр., лауреат Державної премії, кавалер ордена «За заслуги».

Профресор, доктор технічних наук О. Г. Гребеніков - кавалер ордена «Знак пошани», заслужений працівник освіти України, завідувач кафедри проектування літаків і вертольотів з 2007 р.

У процесі розвитку кафедра 103 була основою для фрормування: кафедри міцності літальних апаратів, кафедри проектування ракетно-космічних апаратів; Науково-дослідного інституту проблем фрізичного моделювання режимів польоту літаків (НДІ ПФМ), об'єднаного студентського конструкторського бюро (СКБ), авіамодельної лабораторії, галузевої науково-дослідної лабораторії ресурсу авіаційної техніки, міжнародного навчально-наукового центру CAD/CAM/CAE.

Першим науковим керівником і засновником наукової школи був завідувач кафедри конструкцій літаків (це перша назва кафедри в 1930 р.) Йосип Григорович Неман. Як педагог він започаткував правило «включати в навчальний процес реальне проектування». Це підвищує інтерес до навчання та спонукає підвищувати відповідальність за ухвалення рішення. Як конструктор він створив правила проектування швидкісних літаків.

Пріоритетні напрями розвитку науки і техніки було підтверджено створенням швидкісного літака XAl-1 з удосконаленою аеродинамікою. XAl-1 це пасажирський літак, спроектований та побудований студентами, що пішов у 
серійне виробництво, і це єдиний фракт в історії авіації. В подальшому учасники реального проектування після закінчення XAІ ставали працівниками кафедри та продовжили наукові розробки кафредри. Одночасно під керівництвом П. Г. Бенінга (за участю О. О. Лазарева, Г. А. Кроль) велися роботи зі створення літаків безхвостої схеми. Вже в той час молоді конструктори розробляли літаки за схемою «безхвостки», яку широко застосовують у сучасній авіації.

Розроблено перспективні схеми літаків, що використовують й нині. XAl-1 встановив рекорд швидкості, і вперше в Європі на ньому було реалізовано шасі, що прибиралося з набігаючого потоку повітря в польоті, а на планері «Осоавиахимовец ХАИ» пілот-випробувач Б. Рожков встановив світовий рекорд - 10 мертвих петель на безхвостому планері.

Наукові розробки кафедри були реалізовані в інтересах держави - в 1935 році вже серійний XAІ-1 почав виконувати регулярні рейси Харків - Москва, і цим було започатковано появу «Аерофрлоту» як офріційного пасажирського перевізника. На базі XAI-1 було спроектовано розвідник XAl-5, який також запущено в серію під назвою Р-10. Ведучий конструктор XAI-5 - випускник XAI л. Д. Арсон. Серійний XAІ-5 був на службі в армії та експлуатувався як розвідник.

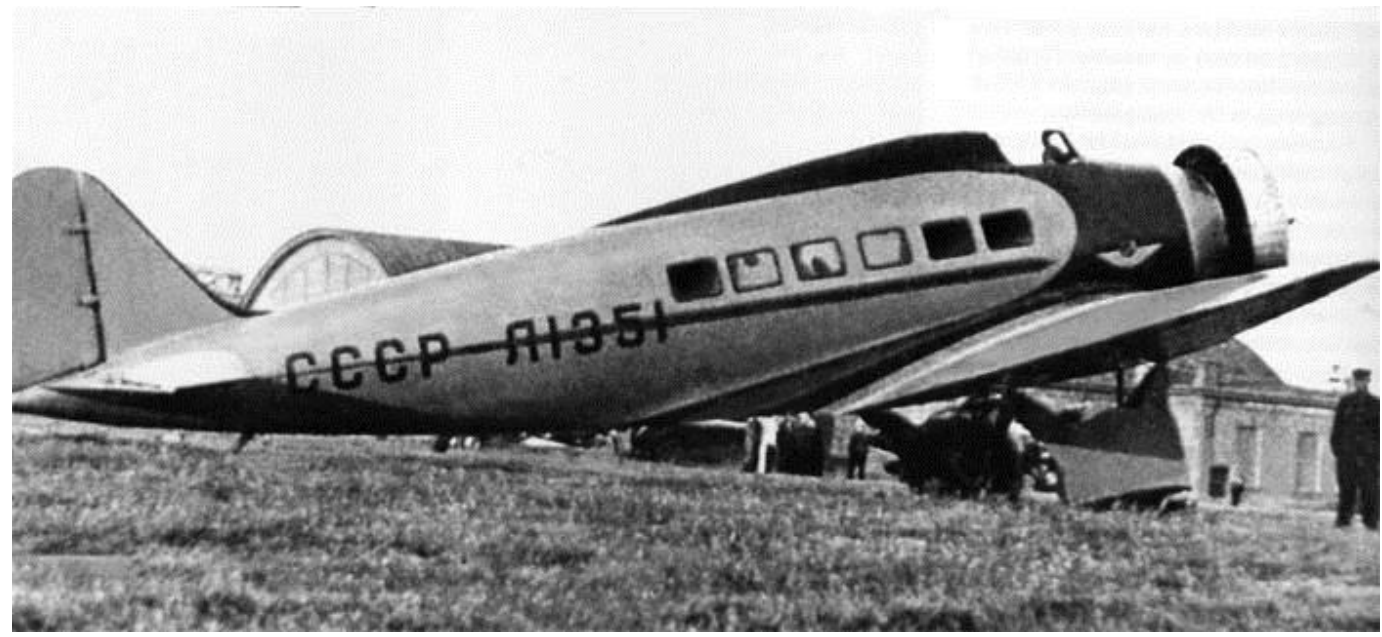

Рис. 2. Літак XAl-1

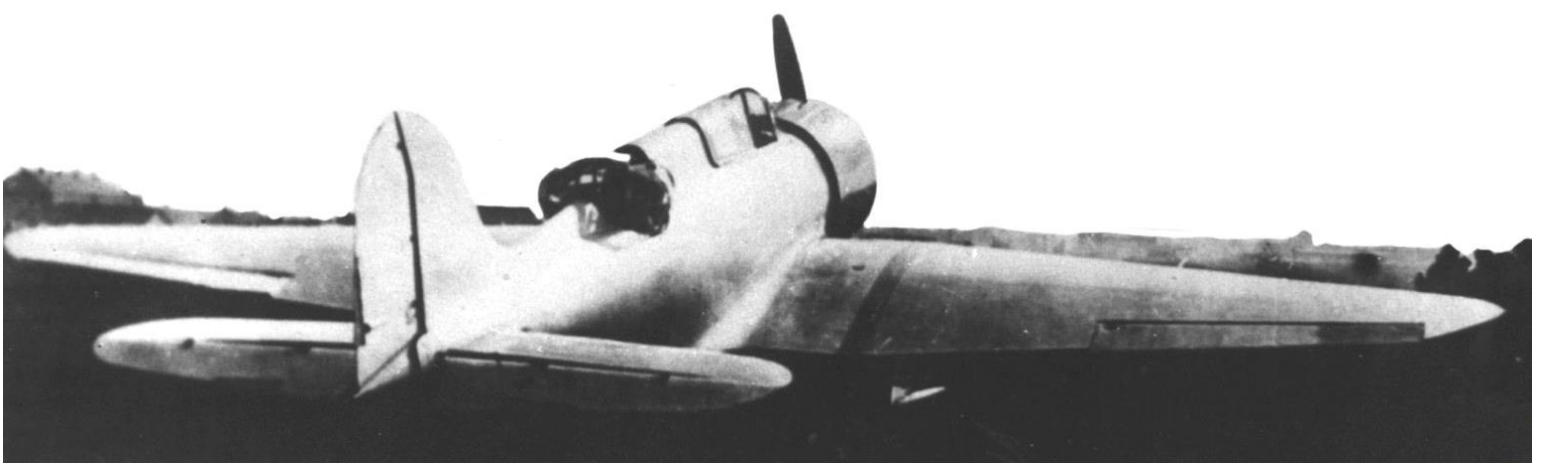

Рис. 3. Літак XAI-5

Під керівництвом профресора Й. Г. Немана на кафедрі конструкції літаків проводилися роботи з вирішення проблеми міцності літаків. Ще в довоєнний період ці наукові результати були втілені при проектуванні XAІ-1. Вже тоді в 
ньому було враховано анізотропію матеріалу дерева, тим самим Й. Г. Неман почав дослідження 3 навантаження композиційних та інших анізотропних матеріалів, чим продовжував займатися в післявоєнні роки. У 50-ті роки тематика наукових досліджень розширювалася. Була підготовлена докторська дисертація Й. Г. Немана на тему «Устойчивость бесконечно длинной ортотропной пластины с наклонными главными направлениями упругости».

У післявоєнні роки викладачі кафедри і студенти брали активну участь у закритому конкурсі ДТСААФ СРСР на проектування легких спортивних літаків. Були виконані проекти спортивних одномісних літаків XAl-12, XAl-13, XAl-14 і чотиримісного туристичного літака XAl-1 3М. Широта охоплення студентів науковою роботою ставила перед кафедрою організаційні питання для вирішення їх у масштабі інституту.

У 1957 році група студентів XAI на чолі 3 В. В. Решетниковим спроектувала спортивний літак. Ідея була схвалена керівництвом інституту, і за допомогою доцента Л. Д. Арсона проект завершили. Літак XAI-17 був побудований силами самих студентів-конструкторів на Київському механічному заводі.

Для залучення широких студентських мас до проектування і будівництва літальних апаратів у 1959 році було створено одне з перших у СРСР і перше в Україні студентське конструкторське бюро (СКБ XАІ). Організатором і науковим керівником СКБ був завідувач кафедри П. В. Дибський, а пізніше - доцент В. М. Ревінов, який спочатку був науковим керівником, а потім і начальником СКБ.

У 1985 році був оголошений конкурс на проектування і спорудження легкомоторного літака для первинного навчання пілотів. Літак повинен був мати мінімальну швидкість зриву, можливість експлуатації на ґрунтових злітнопосадочних смугах і здатність буксирувати планер. Ще при перших розрахунках було вирішено робити літак багатоцільовим - здійснювати патрулювання, аерофотозйомку, пасажирські і вантажні перевезення. Це був масштабний проект, який під керівництвом ректорату і парткому об'єднав творчий потенціал співробітників XАІ та авіаційних підприємств. Керівником проекту був Г. Г. Хмиз.

У 1988 році почалося спорудження літака: на Харківському авіаційному заводі були виготовлені фюзеляж і крила, а на Київському механічному заводі оперення. У 1990 році до 60-річчя Харківського авіаційного інституту літак отримав ім'я XAI-60 "60 років XAI".

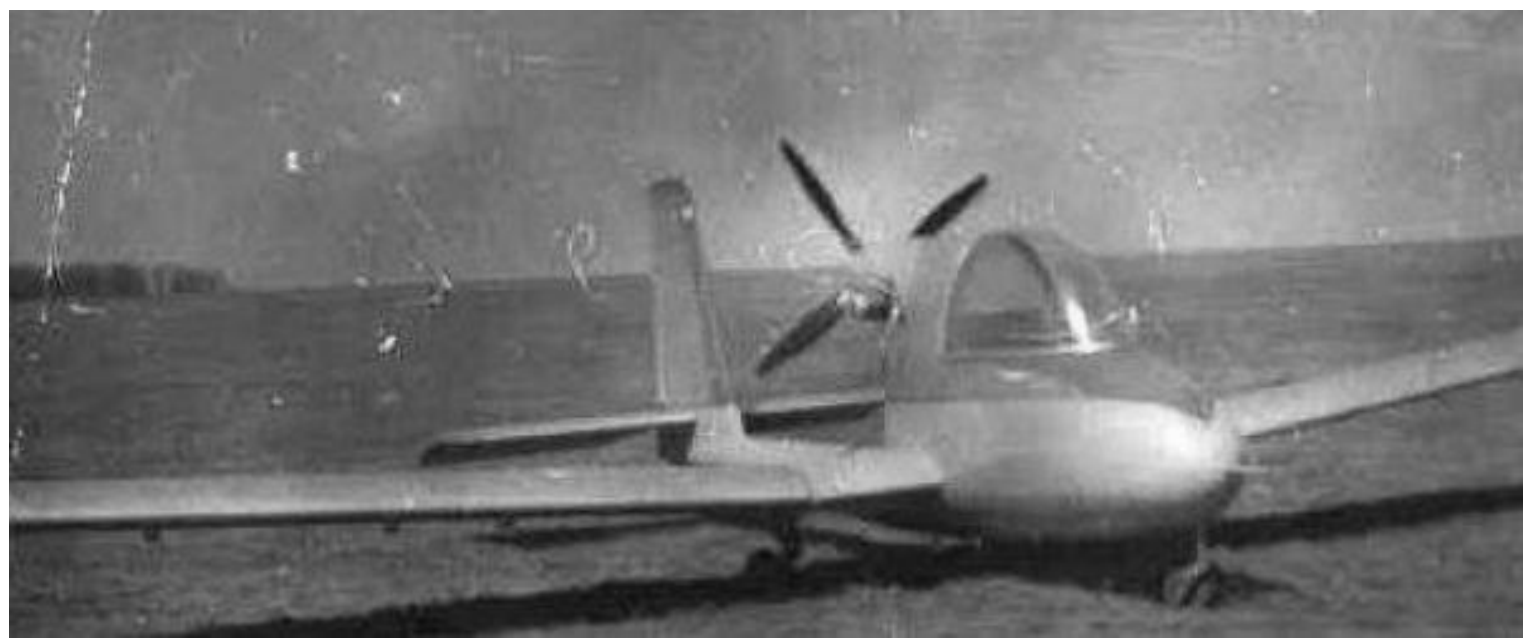

Рис. 4. Літак XAI-17 


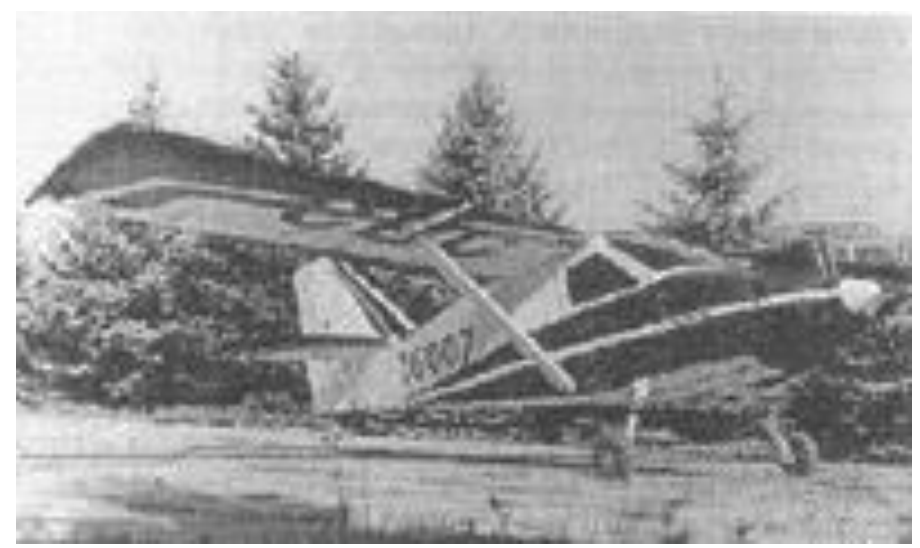

Рис. 5. Літак XAI-60 "60 років XAI"

На базі досвіду створення літаків у СКБ XAІ з допомогою викладачів XAI силами фахівців ХДАВП під керівництвом доктора технічних наук, професора, директора заводу А. К. М'ялиці було розроблено навчально-тренувальний літак ХА3-30. Надійний, простий у виробництві і порівняно недорогий літак було запущено в серійне виробництво на ХДАВП. На ньому проходять навчання курсанти ХУПС імені Івана Кожедуба на базі Харківського аероклубу.

На кафедрі проектування літаків і вертольотів проводиться науководослідна робота щодо створення навчально-тренувального літака з реактивним двигуном на основі накопиченого досвіду в цьому напрямі.

Доцент А. М. Гуменний і асистент Л. Ю. Буйвал зі студентами розробляють аванпроект пасажирського літака XAI-90 - легкий літак для місцевих повітряних ліній з двигунами Al-450, призначений для перевезення пасажирів та вантажу на дальність до 500 км з крейсерською швидкістю 350 км/год.

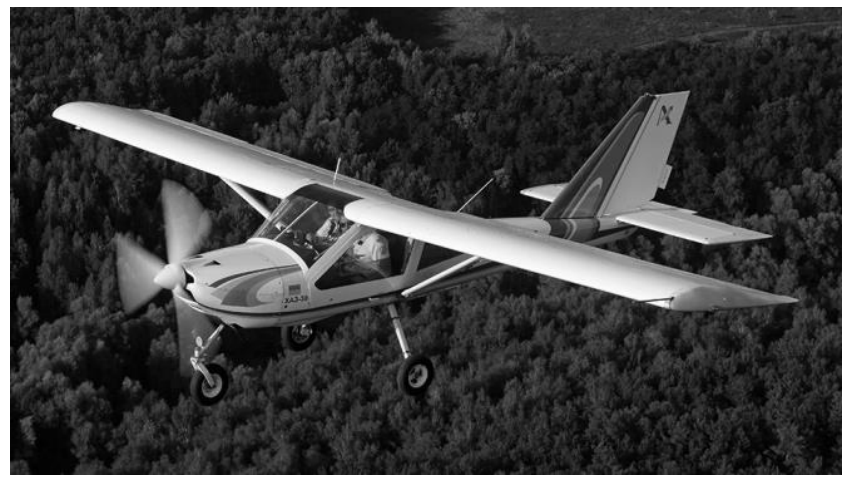

Рис. 6. Навчально-тренувальний літак ХАЗ-30

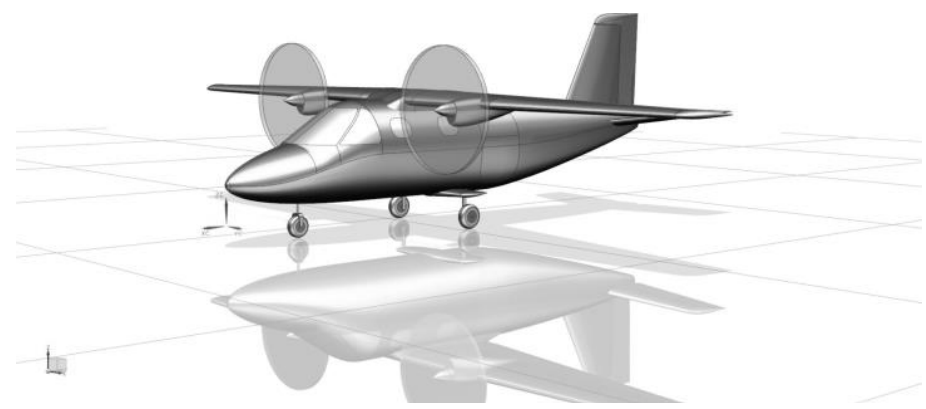

Рис. 7. Модель цивільного легкого літака XАІ-90 
Від 60-х років XX століття фрахівці кафредри проектування літаків і вертольотів розпочали дослідження несучих систем легких вертольотів. Студентським колективом (головний конструктор - Б. І. Мисов, В. І. Буравлев, В. С. Іщук, В. Н. Глушков, А. Н. Роєнко, В. І. Скірко) під науковим керівництвом доцента кафедри В. М. Ревінова та доцента В. К. Золотухіна було спроектовано та виготовлено в СКБ XAІ автожир XAI-24 та двомісний багатоцільовий вертоліт XAI-27 «Харків'янин».

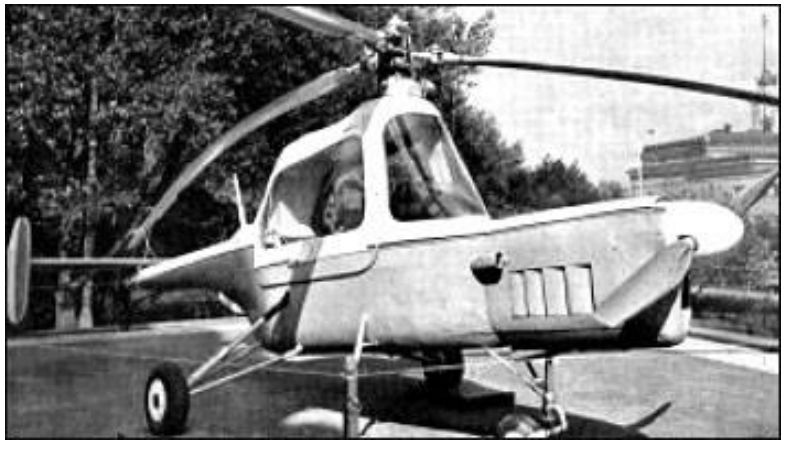

Рис. 8. Автожир XAI-24

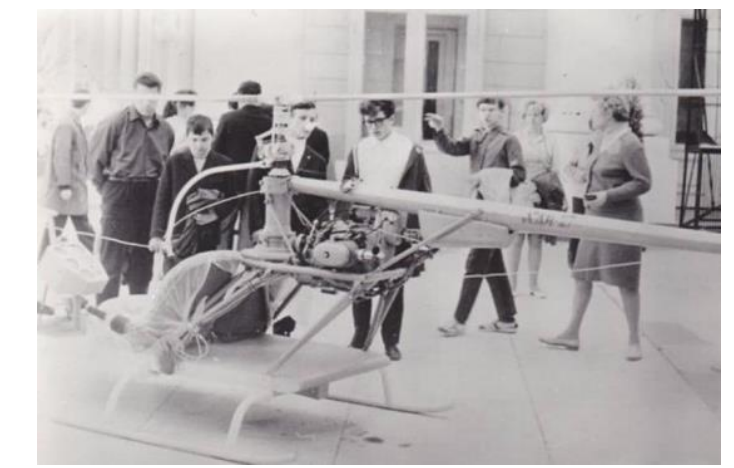

Рис. 9. Багатоцільовий вертоліт XAI-27

Вони демонструвалися на ВДНГ у Москві. Творці вертольотів були нагороджені Дипломами Пошани і золотими, срібними і бронзовими медалями.

Під керівництвом начальника вертолітного відділу кафедри Б. І. Мисова вирішувалася проблема автоматизованого завантаження добривами на сільськогосподарський варіант вертольота Ка-26. Співробітники кафедри проводили випробування на втомну довговічність елементів композитної лопаті легкого вертольота.

Викладацьким складом кафедри (профресор Л. І. Лосєв, профресор О.Г. Гребеніков, доцент Б. А. Панасенко, доцент А. М. Тимченко, доцент В. А. Урбанович, старший викладач А. С. Чумак, асистент К. Ю. Вишняков) розроблено методичне забезпечення за методологією проектування гвинтокрилих літальних апаратів. Кафедра співпрацює 3 АТ "Мотор Січ" над модернізацією легкого вертольота МСБ-2. На кафедрі конструкцій літаків

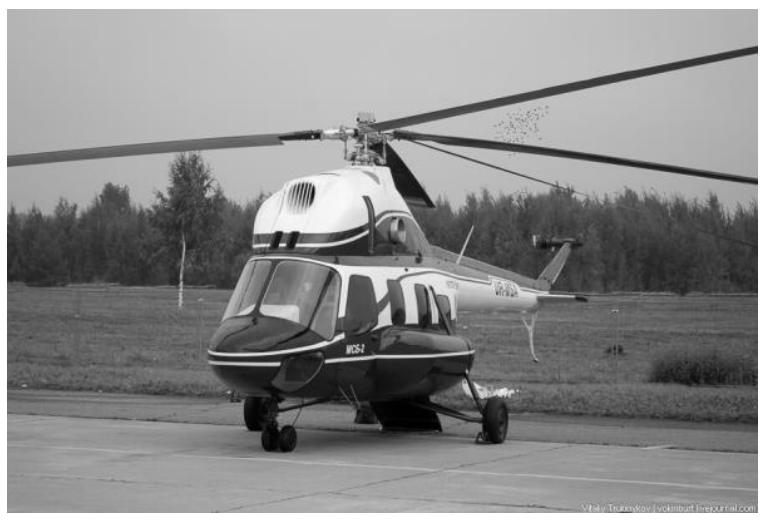

Рис. 10. Легкий вертоліт МСБ-2 під керівництвом П. В. Дибського, Ф. Г. Ясинського, О. Р. Черановського

та О. І. Риженка було створено новий науковий напрям - дослідження аеродинамічних характеристик профілів крила в умовах вільного польоту в реальній атмосфері. Так з'явилися безпілотні літальні лабораторії, що $\epsilon$ прототипом багатьох літакових конструкцій. Численні дослідження, проведені викладачами і молодими інженерами кафедри, наштовхнули останніх на думку - виготовити великомасштабну модель літака і виконати наукові дослідження в умовах польоту. Авторів цих робіт можна вважати основоположниками безпілотників. 
24 червня 1959 року при XАІ був створений науково-дослідний відділ льотних досліджень радіокерованих моделей (НДВ ЛДРКМ) під керівництвом доцента П. В. Дибського. НДВ ЛДРКМ розробляв методики застосування літальних моделей для дослідження аеродинамічних характеристик літаків і впроваджував їх у практику льотних досліджень. У рамках цих робіт були проведені дослідження проблем аеродинаміки примежового шару.

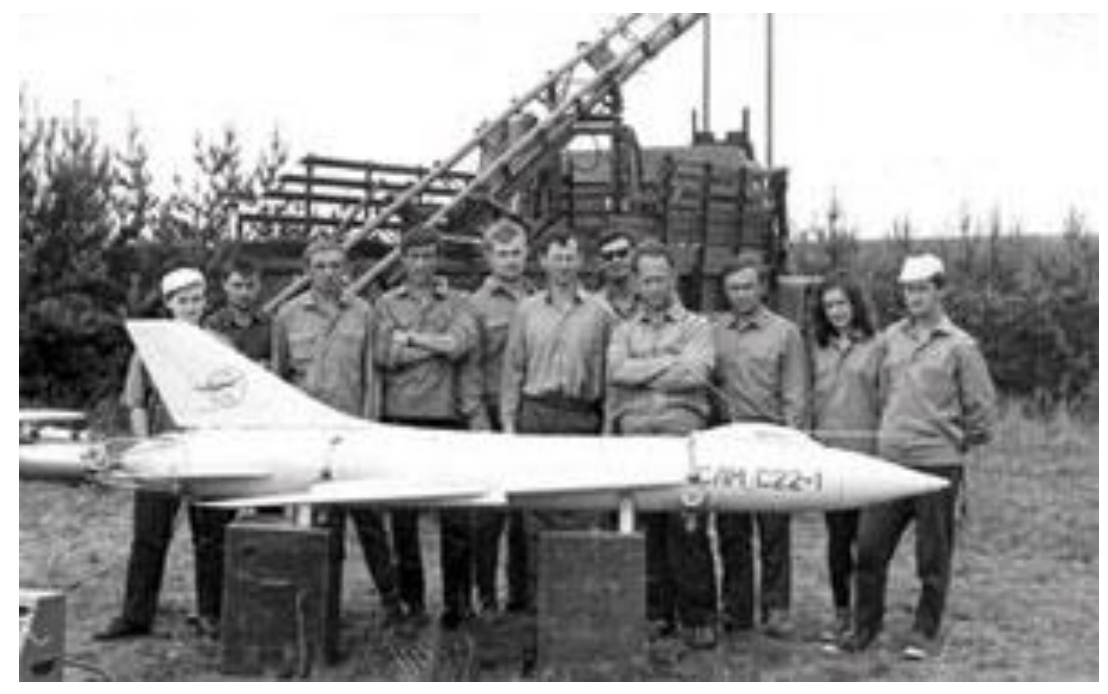

Рис. 11. Вільно літаюча динамічно-подібна модель (ВДПМ) СлМС-22

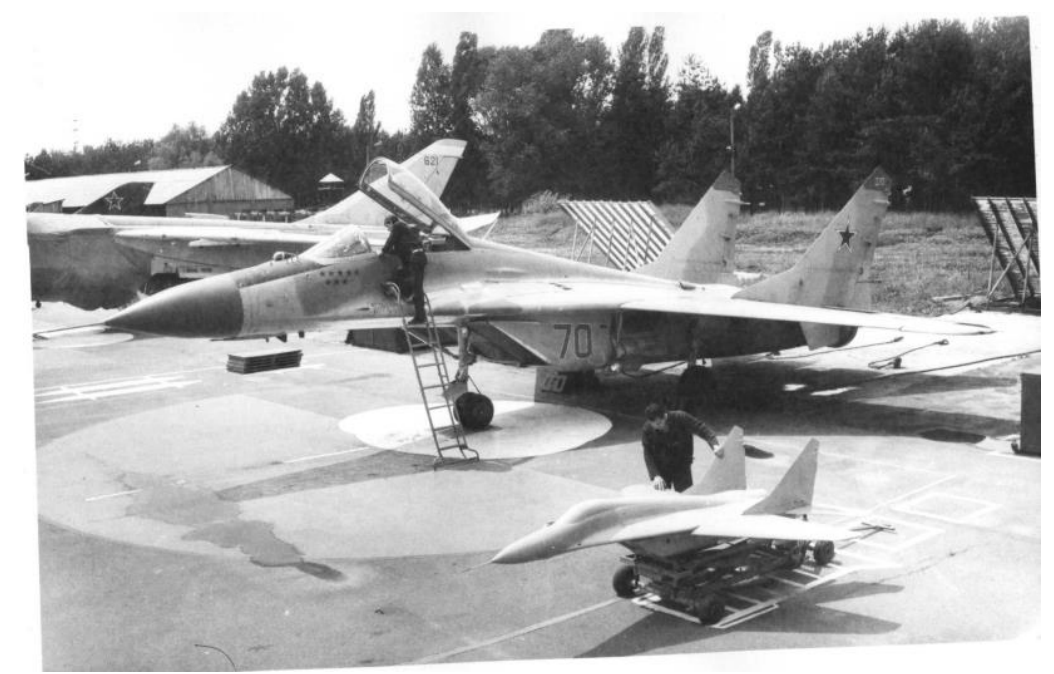

Рис. 12. МіГ-29: літак та вільно літаюча динамічно-подібна модель

У 1972 році були проведені льотні експерименти з дослідження небезпечних режимів звалювання і штопора літака. 3 урахуванням позитивного ефекту від виконаних робіт 25 грудня 1978 року була утворена галузева науково-дослідна лабораторія великомасштабних дистанційно пілотованих моделей (ГНДЛ-3).

З 1989 року директором ГНДЛ-3, а потім і Науково-дослідного інституту проблем фрізичного моделювання режимів польоту літаків (НДІ ПФМ), який був створений на базі галузевої лабораторії, став О. Р. Черановський. Вперше в світі на безпілотних моделях літаків перевіряли невідомі й небезпечні режими польотів, що дозволяло скоротити час на дослідження, а також зберегти життя 
пілотів і реальні літаки. Діяльність НДІ ПФМ була нерозривно пов'язана 3 провідними авіаційними фрірмами СРСР. В інституті були створені і випробувані моделі літаків ДКБ ім. П. О. Сухого, ДКБ ім. А. І. Мікояна, ДКБ ім. В. М. М'ясищева.

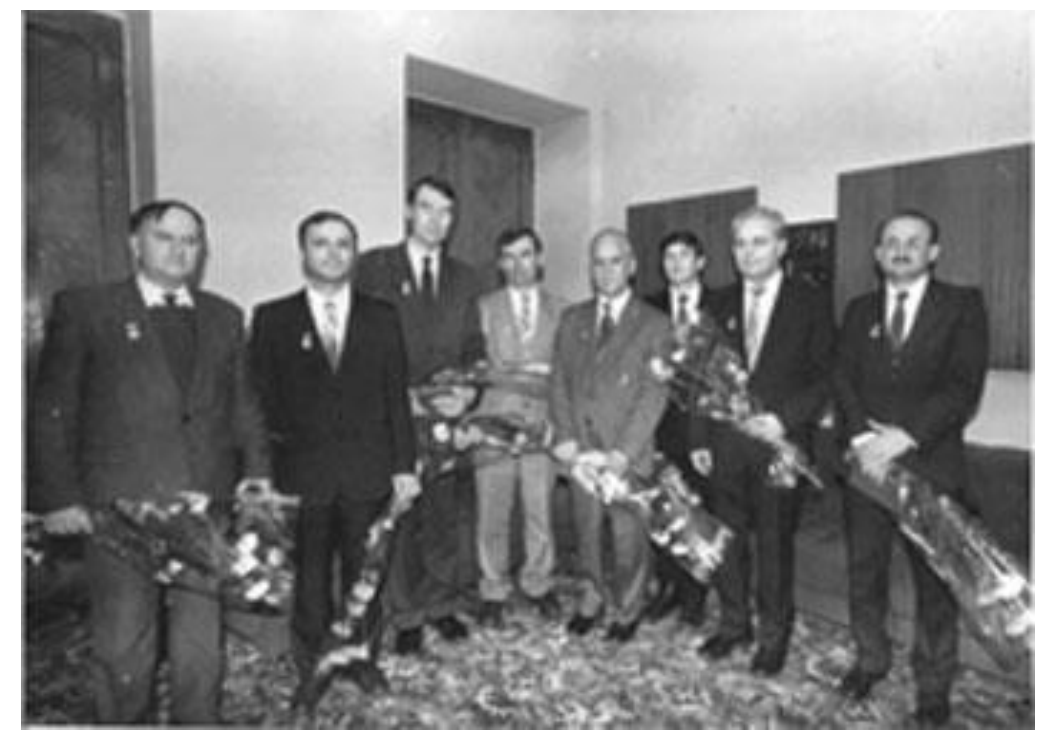

Рис. 13. Група лауреатів Державної премії

Довгий час науковим керівником у НДІ ПФМ був професор В. І. Рябков.

За результатами наукових робіт група фрахівців В. Д. Білий, С. А. Яшин, О. І. Риженко, С. М. Садівничий, О. Р. Черановський, В. О. Яценко, В. І. Рябков, О. В. Бетін - зліва направо на фото на рис. 13) отримала Державну премію в галузі науки і техніки.

НДІ ПФМ багато років працював над створенням ВДПМ військових і цивільних літаків, що розробляються. Тепер така практика широко застосовується у всьому світі. ВДПМ дозволяють отримати найбільш достовірні дані про льотні характеристики літака на різних режимах польотів і дати відповіді на питання конструкторів і випробувачів ще в процесі розроблення.

Далі науково-дослідна робота кафедри розгалужується на декілька напрямів.

31964 р. колективи кафедр конструкцій і міцності літальних апаратів проводили дослідження 3 метою розроблення конструкцій підвищеного ресурсу і методів їх проектування 3 урахуванням втоми під керівництвом кандидата технічних наук, доцента кафедри Л. Д. Арсона.

У 1978 році на основі виконаних досліджень у XAІ за допомогою ректорату, ЦАГІ та Генерального конструктора О. К. Антонова була створена галузева лабораторія з'єднань літакових конструкцій підвищеного ресурсу у складі кафедри конструкцій літальних апаратів, яку очолили Л. Д. Арсон та Л. О. Малашенко.

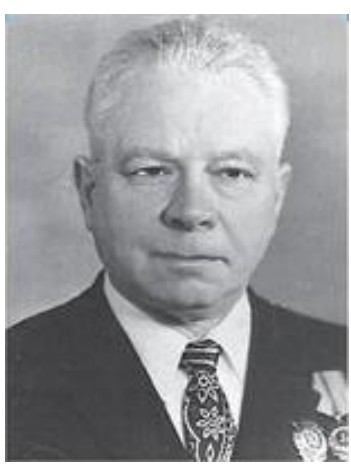

Рис. 14. Доцент Л. Д. Арсон

У лабораторії були сформовані такі підрозділи:

1. Відділ крила й оперення (науковий керівник - О. Г. Гребеніков).

2. Відділ фюзеляжу (науковий керівник - А. Г. Лебединський).

3. Відділ шасі і керування (науковий керівник - В. І. Рябков). 
4. Відділ надійності (науковий керівник - Л. О. Малашенко).

У наукових дослідженнях лабораторії брали участь практично всі працівники кафедри і багато студентів. Фахівці лабораторії виконували наукові роботи на замовлення авіапідприємств усього Радянського Союзу.

Під керівництвом Л. Д. Арсона розроблені методи проектування конструкцій підвищеного ресурсу з урахуванням втоми, захистили кандидатські дисертації В.І.Рябков, О. Г. Гребеніков, А. Г. Лебединський.

Під керівництвом О. Г. Гребенікова розроблено і впроваджено в авіаційну промисловість і навчальний процес методологію інтегрованого проектування збірних літакових конструкцій регламентованої довговічності, захистили кандидатські дисертації М. М. Федотов, В. М. Андрющенко, С. В. Трубаєв, О. М. Тимченко, Є. Т. Василевський, А. П. Еретін, В. М. Клименко, А. М. Гуменний, В. М. Смирнов, О. Д. Донець.

Під керівництвом А. Г. Лебединського були проведені дослідження заклепочних з'єднань елементів літакових конструкцій. Захистили кандидатські дисертації А. А. Редько, Л. П. Семенов.

На базі лабораторії під керівництвом В. І. Рябкова розроблені принципи і методи синтезу параметрів шасі за критерієм довговічності, захистили кандидатські дисертації Т. П. Цепляєва (надалі професор XAI, відмінник освіти України, кавалер ордену княгині Ольги III ступеня), С. Є. Шеметов, І. В. Волох, М. Г. Толмачов, О. В. Лось, Д. В. Тиняков. Одним із напрямків наукової школи став напрямок «Тахіонна енергія: властивості, параметри, шляхи використання в ракетно-космічній і авіаційній техніці», утворений в 1999 році під керівництвом В. І. Рябкова. Був змодельований і реалізований процес виділення тахіонної енергії, встановлені джерела і визначені значення параметрів носіїв цього виду енергії, а також можливості використання тахіонної енергії в силових установках літальних апаратів.

Під керівництвом Л. О. Малашенка розроблені методи проектування збірних конструкцій літальних апаратів з урахуванням випадкових чинників, захистили кандидатські дисертації С. Г. Левченко, С. А. Арасланов, М. В. Сінкевич, Л. В. Капітанова.

На кафедрі під керівництвом Ф. Г. Ясинського розроблені методи оптимального проектування авіаційної техніки, захистили кандидатські дисертації А. І. Андрієнко, О. А. Цирюк, О. І. Риженко.

Результати наукових досліджень впроваджені на авіаційних підприємствах України та стран СНГ.

На основі новітніх досягнень у галузі проектування і технології виробництва фрахівці авіаційних підприємств України створили літаки Ан-70, Ан74TК-300, Ан-140, Ан-148, Ан-132, Ан-158, Ан-74ТК-200, Ан-124. В створення цих літаків значний вклад внесли співробітники кафедри та наші випускники, які становлять більше $50 \%$ наукових працівників авіаційних підприємств. I нині ведуться роботи, спрямовані на створення нових модифікацій цих літаків.

За підтримки О. К. Антонова сфрормувався новий напрям студентської науково-технічної творчості щодо створення різних типів літальних апаратів. За його ініціативою для прискорення створення конструкторської і технологічної документації літака Ан-124 "Руслан" до Києва були запрошені на роботу і навчання найбільш підготовлені студенти. Досвід, що був започаткований ще при проектуванні літака XAl-1, поєднання навчального процесу 3 реальним дипломним і курсовим проектуванням виявився вдалим. 
Форми організації навчального процесу за участю КМЗ і XАІ розвиваються і в подальшому. Продовжено традиції тісної співпраці і науки, освіти і виробництва.

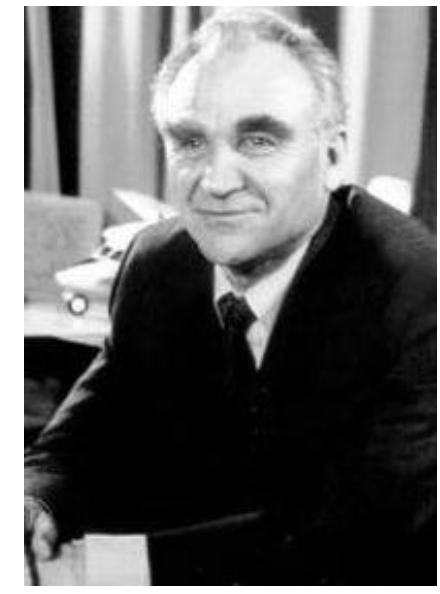

Рис. 15. П. В. Балабуєв,

Генеральний конструктор, професор, доктор технічних наук, Герой України,

Герой Соціалістичної Праці, лауреат Державної премії

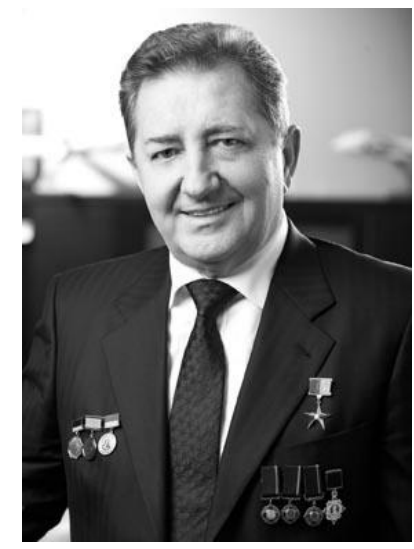

Рис. 16. Д. С. Кива,

Генеральний конструктор, Герой України, профресор, доктор технічних наук,

академік НАН України, заслужений діяч науки і техніки України, лауреат Державної премії, кавалер ордена «За заслуги» I, II, III ступенів

Профресорами кафредри, яку свого часу очолював О. К. Антонов, працювали випускники XAІ доктори технічних наук Генеральний конструктор П. В. Балабуєв, Генеральний конструктор Д. С. Кива, Генеральний директор АНТК ім. О. К. Антонова В. Н. Король, головний інженер С. А. Бичков.

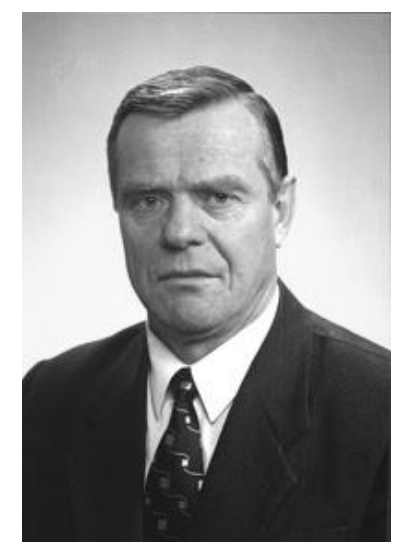

Рис. 17. С. А. Бичков, головний інженер, профресор, доктор технічних наук, заслужений працівник промисловості України, кавалер ордена «За заслуги» I, II, III ступенів, кавалер Національного французького ордена «За заслуги»

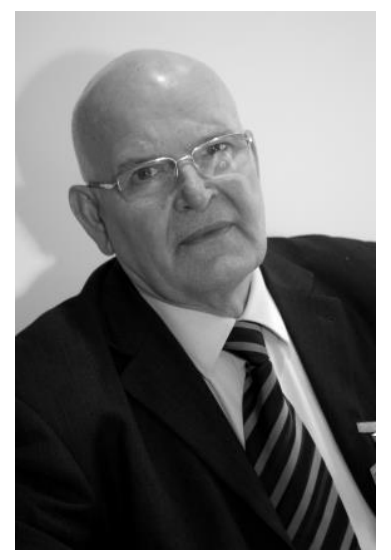

Рис. 18. А. К. М'ялиця, Профресор, доктор технічних наук, Герой України, лауреат Державної премії, екс-директор ХДАВП, екс-міністр промислової політики України

При вирішенні завдань розвитку авіаційної промисловості важлива роль відводиться комп'ютерним інтегрованим системам, застосування яких істотно 
скорочує витрати i терміни створення літаків, підвищує якість і конкурентоспроможність авіаційних проектів. Застосування відкритих інформаційних і комп'ютерних інтегрованих технологій (КІT) також $є$ основою якості і ефективності виробництва, науки і навчального процесу.

Впровадження КІТ здійснюється на усіх етапах життєвого циклу авіаційної техніки: виробництві, випробуваннях, сертифікації, збуті, експлуатації, сервісному обслуговуванні, утилізації. База даних про виріб має бути доступною для постачальника, розробника, замовника, експлуатанта.

\section{Навчально-науково-виробничий центр CAD/CAM/CAE/PLM}

У 1993 р. для реалізації стратегії впровадження сучасних комп'ютерних технологій на базі Харківського авіаційного інституту був створений Навчальний центр з вивчення систем CAD/CAM/CAE. В організації центру взяли участь американські фрірми Digital i EDS, АНTK ім. О. К. Антонова, XAI і АНTC «КНК». Начальником центру було призначено доцента О. Г. Гребенікова.

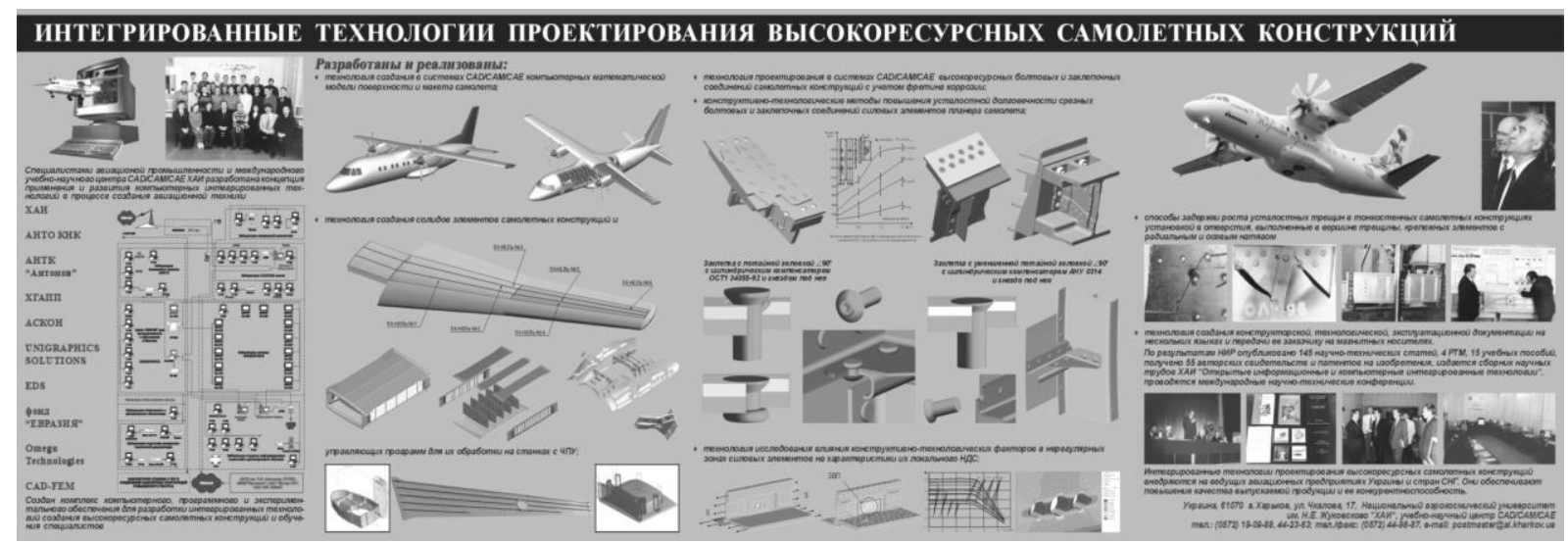

Рис. 19. Напрямки роботи центру з вивчення систем CAD/CAM/CAE

Основні завдання Навчального центру - підготовка висококваліфікованих технічних фрахівців, що вільно володіють прийомами і методами роботи на сучасних програмно-технічних комплексах; підготовка і перепідготовка фахівців промисловості для оволодіння прийомами і методами роботи на сучасних програмно-технічних комплексах.
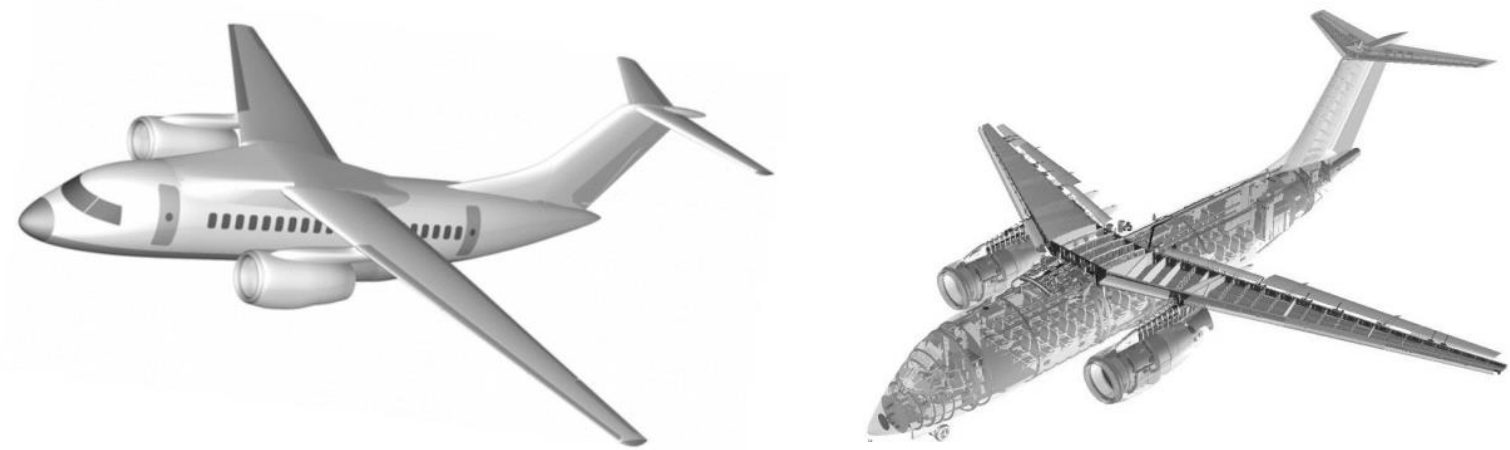

Рис. 20. Літак Ан-148: майстер-геометрія і модель розподілу простору 
У центрі організовано навчальний процес, навчально-методичну і науково-дослідну роботу, пов'язану з проектуванням і комп'ютерним моделюванням прогресивної авіаційної техніки. В Навчально-науковому центрі CAD/CAM/CAE XAI розроблено методологію створення авіаційної техніки за допомогою систем UNIGRAPHICS, ANSYS, ADEM, KOMПAC, Siemens NX, CATIA.

За час свого існування центр зарекомендував себе на міжнародному рівні і перетворився на Міжнародний навчальнонауковий центр відкритих інформаційних і комп'ютерних інтегрованих технологій. Фахівці центру підтримують міжнародні зв'язки з фахівцями США, Росії, Німеччини, Чехії, Канади, Японії, Ірану, Індії, Китаю і Мексики. На базі навчально-наукового центру проводяться міжнародні науковометодичні конференції, видається

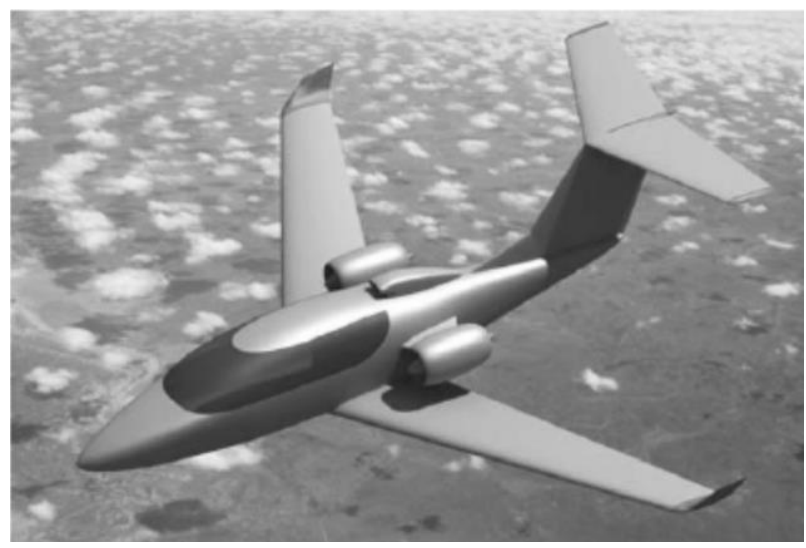

Рис. 21. Майстер-геометрія перспективного літака

збірка наукових праць XAI "Відкриті інформаційні і комп'ютерні інтегровані технології", розробляється і видається навчально-методична, наукова і технічна документація.

Фахівцями центру розроблені і реалізовані: технологія створення в системі CAD/CAM/CAE комп'ютерного еталону поверхні і макетів агрегатів літака; технологія створення твердотілих моделей елементів літакових конструкцій і керуючих програм для оброблення цих елементів на верстатах 3 ЧПУ; інтегровані технології проектування високоресурсних з'єднань літакових конструкцій; технологія створення конструкторської, технологічної, експлуатаційної документації на декількох мовах з подальшою її передачею замовникові в електронному вигляді на носіях різного типу і по мережі Internet; методика навчання студентів, працівників промисловості та освіти створенню аерокосмічних об'єктів на базі комп'ютерних інтегрованих систем. Комплекс цих розробок впроваджений на авіаційних підприємствах і в авіаційних конструкторських бюро України і країн СНД. Він може бути застосований на машинобудівних підприємствах, у наукових і навчальних закладах.

Нині наукова школа «Проектування і конструювання авіаційної ефрективної високоресурсної техніки» зосереджена на розробленні трьох напрямків наукової діяльності:

1. Методологія інтегрованого проектування, конструювання та моделювання за допомогою сучасних систем CAD/CAM/CAE високоефективної авіаційної техніки

Керівник - О. Г. Гребеніков, завідувач кафедри, доктор технічних наук, профресор.

Цей напрямок наукової діяльності містить:

- Розроблення методології інтегрованого проектування, конструювання та тривимірного параметричного моделювання за допомогою сучасних систем CAD/CAM/CAE високоефективної пілотованої і безпілотної авіаційної техніки. 
- Удосконалення методів і методик інтегрованого проектування, конструювання та тривимірного параметричного моделювання високоефективної авіаційної техніки.

- Розроблення та удосконалення конструктивно-технологічних методів забезпечення заданого ресурсу авіаційної техніки.

- Розроблення аванпроектів зразків високоефективної авіаційної техніки.

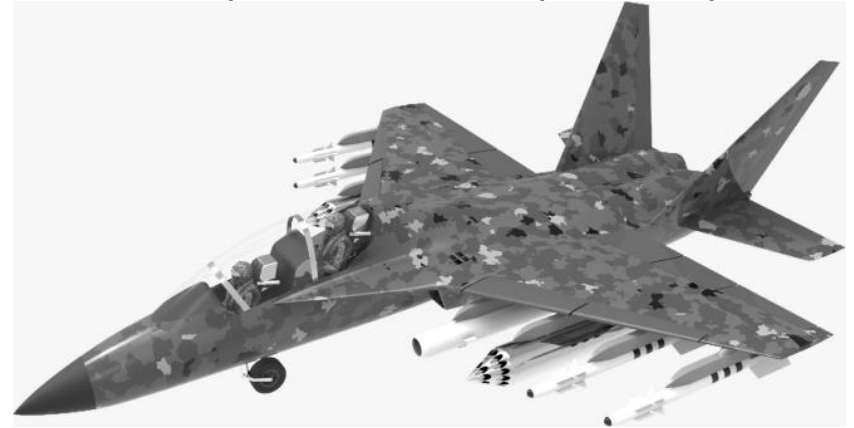

Рис. 22. Майстер-геометрія навчальнобойового літака НБЛ-2

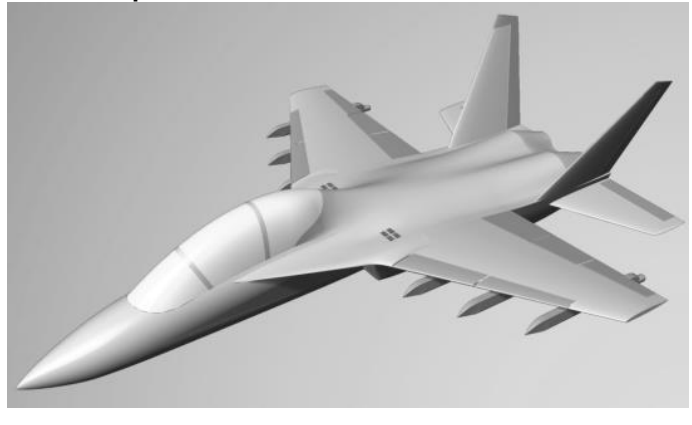

Рис. 23. Майстер-геометрія навчально-бойового літака НБЛ-3

2. Проблеми створення модифрікацій літаків транспортної категорії 3 урахуванням їх конкурентоспроможності

Керівник - В. І. Рябков, доктор технічних наук, професор.

Цей напрямок наукової діяльності містить:

- Забезпечення ефективності і конкурентоспроможності модифікацій літаків транспортної категорії на основних етапах їх життєвого циклу.

- Удосконалення методів і методик оцінювання модифікаційних змін у літаках транспортної категорії за техніко-економічними показниками.

- Розроблення методу i моделей забезпечення ефрективності модифікаційних змін у геометрії трапецієподібних крил.

- Використання отриманих наукових результатів для забезпечення конкурентоспроможності модифікацій Ан-140-200 за умовами змін у крилі і шасі модифікації.

3. Наукові основи ефективної експлуатації, технічного обслуговування та ремонту авіаційної техніки

Керівник - М. М. Орловський, кандидат технічних наук, доцент.

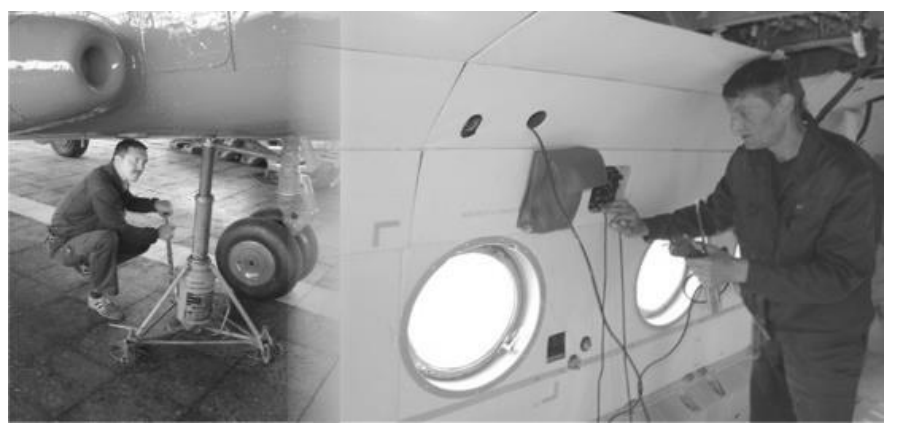

Рис. 24. Технічне обслуговування та ремонт авіаційної техніки

- Методологічні основи підтримання
Даний напрямок наукової діяльності містить:

- Вирішення проблеми забезпечення та підтримання льотної придатності авіаційної техніки з урахуванням сучасного техніко-економічного стану цивільної авіації. - Сучасний стан проблеми забезпечення та підтримання льотної придатності авіаційної техніки.

льотної придатності авіаційної техніки. 

техніки.

- Розроблення процедури контролю льотної придатності авіаційної

На кафедрі створені умови для виконання науково-дослідних робіт, зокрема працює лабораторія ресурсу авіаційних конструкцій, навчальнонауковий центр CAD $\backslash \mathrm{CAM} \backslash \mathrm{CAE}$.

На базі кафедри і навчально-наукового центру CAD/CAM/CAE проходять наукові стажування фрахівці України, Ірану, Китаю.

Фахівцями кафедри розроблені та виконуються програми спільних науково-дослідних робіт із ДП «Антонов» та АТ «Мотор Січ».

За результатами науково-дослідної роботи викладачами кафедри отримано 172 авторських свідоцтва на винаходи, опубліковано ффундаментальні наукові і навчальні видання «Качество и сертификация промышленной продукции», «Основы изобретательской деятельности», «Основы общего проектирования самолетов с газотурбинными двигателями», «Основы работы в сети Internet», «Методология интегрированного проектирования и моделирования сборных самолетных конструкций», «Проектирование тяжелых одновинтовых вертолетов и их трансмиссий», «Моделирование объектов авиационной техники с помощью системы «Компас», «Анализ напряженно-деформироваиного состояния авиационных конструкций с помощью системы ANSYS», «Разработка аванпроекта самолета», «Основы конструирования элементов аэрокосмической техники», «Основы аэрокосмической техники», «Інженерні основи фрункціонування і загальна будова аерокосмічної техніки», «Конструкция самолетов и вертолетов», «Устройство и выбор параметров шасси самолетов», «Интегрированное проектирование и моделирование высокоресурсных растянутых панелей крыла транс-портного самолета», «Разработка аванпроекта вертолета»,

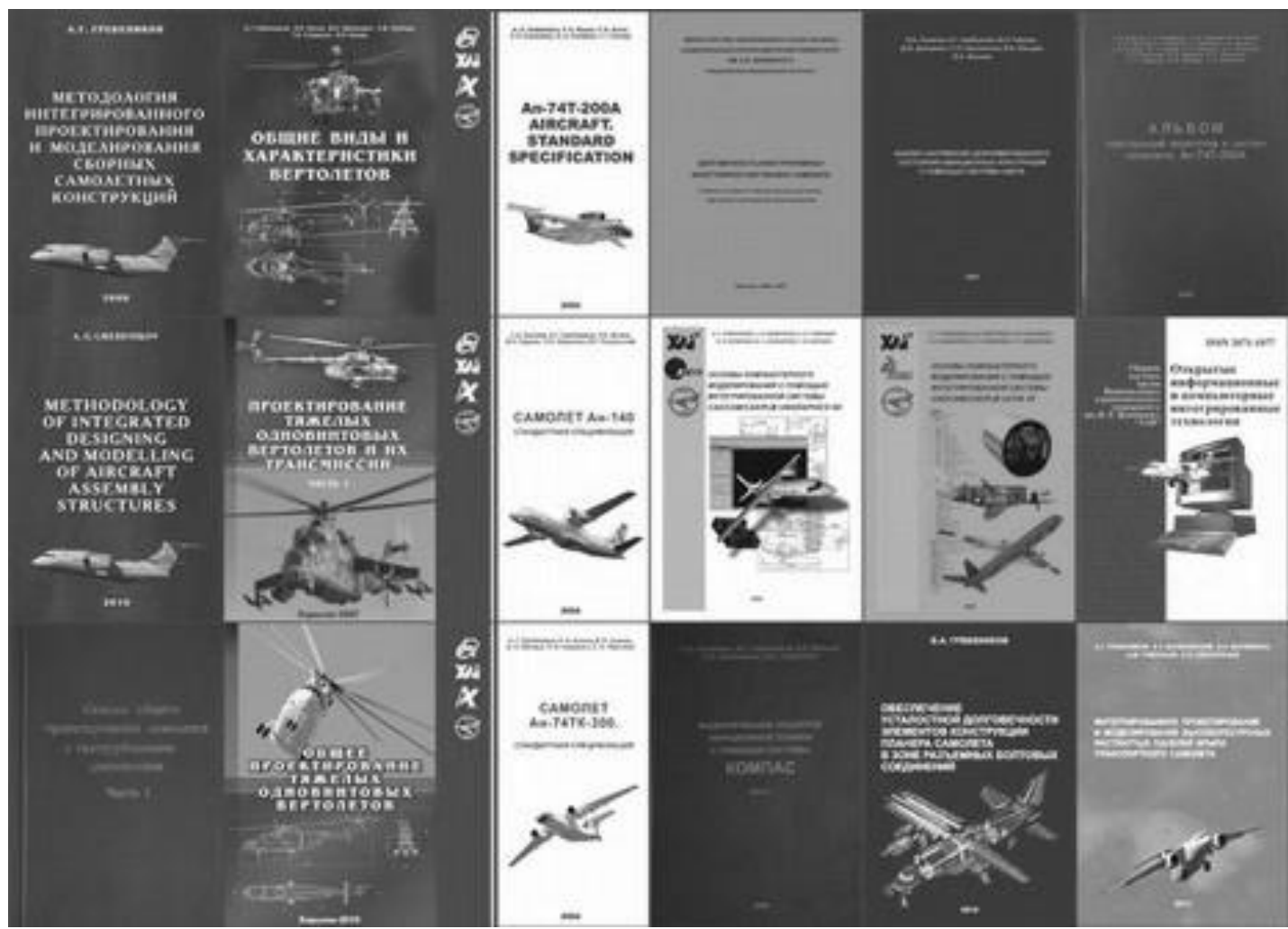

Рис. 25. Наукові та навчальні видання 
«Противообледенительные системы самолетов и вертолетов», «Научные основы интегрированного проектирования самолетов транспортной категории», «Методологія інтегрованого проектування збірних літакових конструкцій регламентованої довговічності», «Основи загального проектування літаків 3 газотурбінними двигунами», «Интегрированное проектирование винтокрылых летательных аппаратов транспортной категории», «Научные основы конструктивно-технологических методов обеспечения ресурса авиационной техники», "Scientific Grounds of Structural and Production Concepts to Provide Aircraft Life Time».

На кафедрі постійно проводять науково-технічні семінари. Викладачі кафедри беруть участь у науково-технічних конференціях, зокрема таких, як Міжнародна науково-технічна конференція «Проблеми створення та забезпечення життєвого циклу авіаційної техніки»; Всеукраїнська науковотехнічна конференція «Інтегровані комп'ютерні технології в машинобудуванні»; міжнародні конгреси двигунобудівників; Міжнародна науково-технічна конференція «АВІА-2017», науково-технічні конференції, що проводять у рамках Міжнародного авіаційного салону ABIACBIT, та інші. За останні п'ять років опубліковано 190 тез наукових доповідей.

Фахівці кафедри є постійними учасниками виставок і Міжнародного авіаційного салону АBIACBIT.

Фахівці наукової школи приділяють велику увагу навчально-виховному процесу.

На базі кафедри проводять II етап Всеукраїнської відкритої студентської олімпіади зі спеціальності «Авіаційна та ракетно-космічна техніка», II етап Всеукраїнського конкурсу студентських наукових робіт за спеціальностю «Авіаційний транспорт», науково-практичні конференції учнівської молоді "Гагарінські читання".

Наші студенти беруть участь у всеукраїнських студентських олімпіадах і конкурсах наукових робіт, де стають переможцями та призерами, серед них: О. Лук'янов, О. Сахно, С. Деркач, О. Джуринський, А. Захарчук, О. Соболєв, С. Сікульський, Н. Скомаровський, В. Косарев, Б. Маловічко, С. Журавель, А. Бочко, О. Красновольська, І. Таран, Є. Комар, Д. Жиряков, Є. Духняк, Є. Шевченко, В. Поляков, О. Довженко, А. Глибченко, І. Іваночко, О. Колоша.

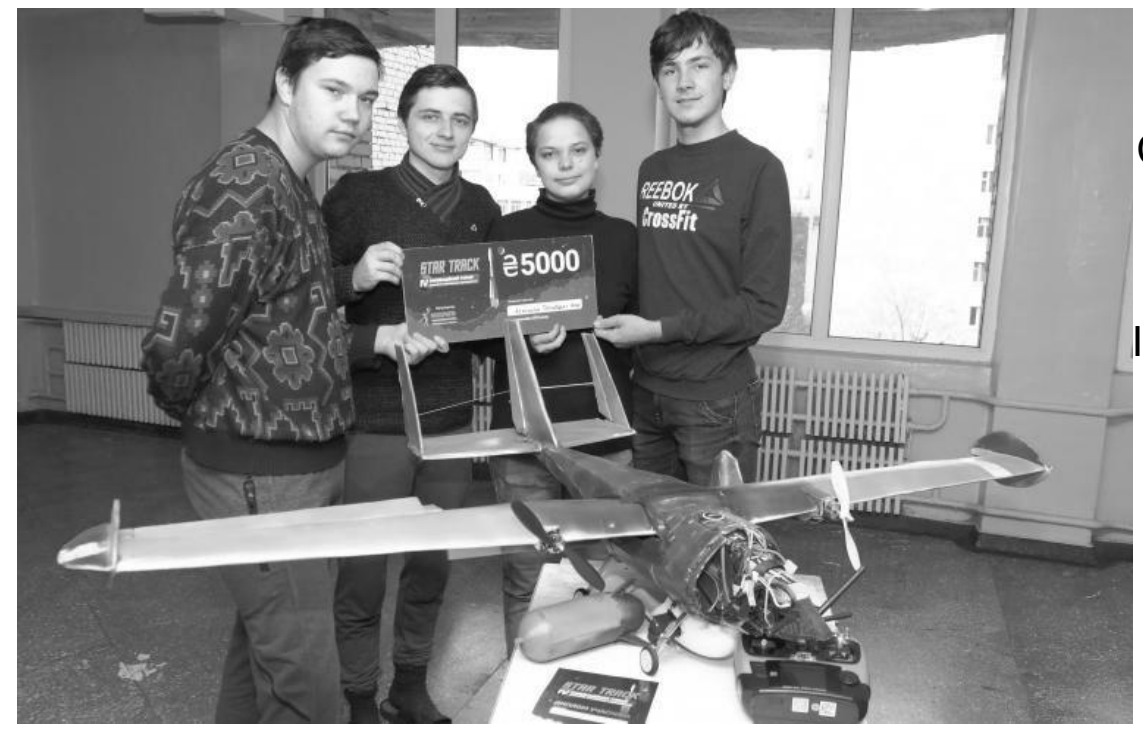

Рис. 26. Переможці у категорії «Ракета-носій CanSat та апарати типу CanSat» турніру Star Track, серед яких студенти кафедри 103 Ігор Іваночко та Олексій Колоша 


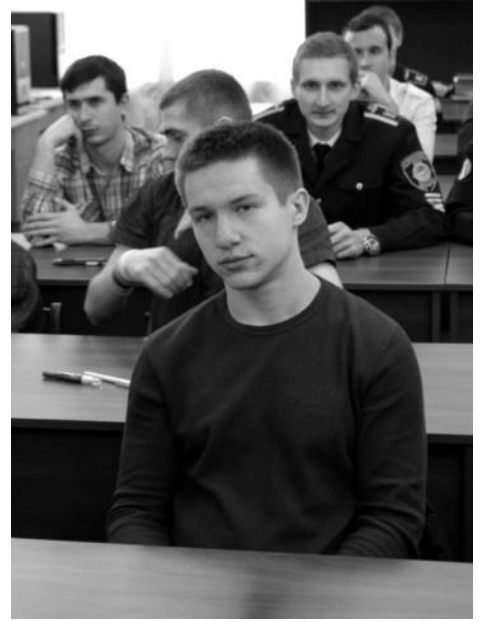

Рис. 27. Сікульський Станіслав - переможець конкурсів АВIATOP - 2012, 2013, отримав дипломи магистра XAl і Ембри

Ріддл університету аеронавтики (США) за програмою академічної мобільності

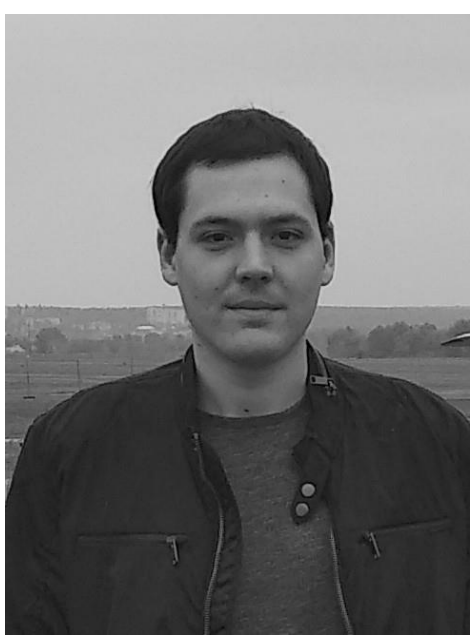

Рис. 28. Соболєв

Олександр - переможець II етапу Всеукраїнської студентської олімпіади «Авіаційна та ракетнокосмічна техніка» - 2014

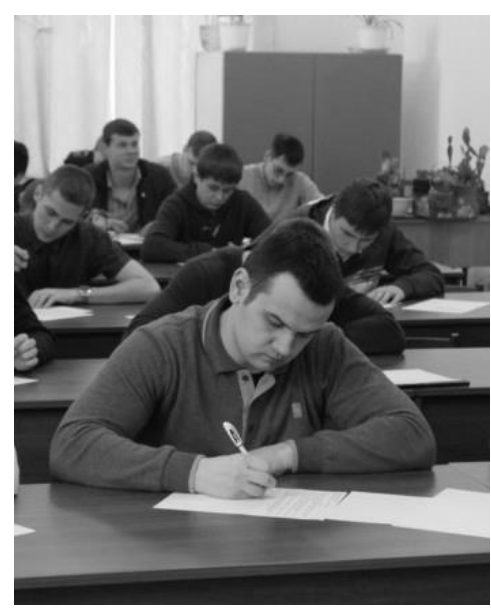

Рис. 29. Журавель Сергій -переможець II етапу Всеукраїнської студентської олімпіади «Авіаційна та ракетнокосмічна техніка» - 2015

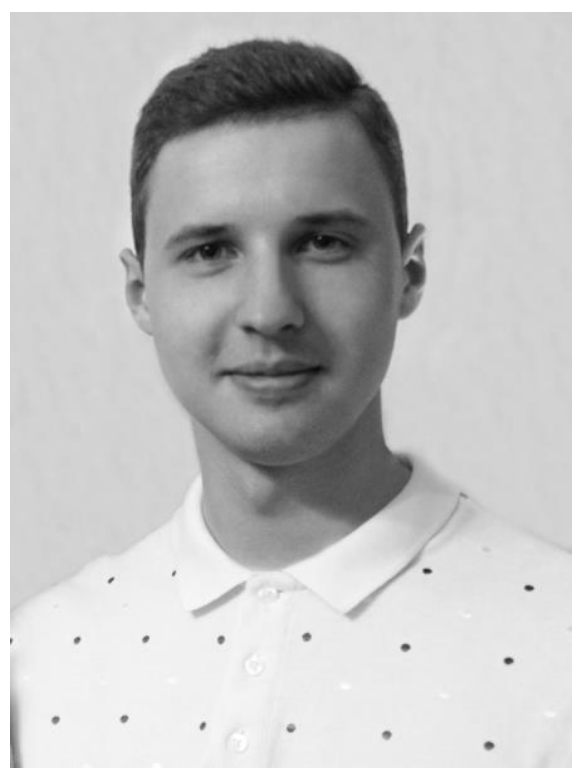

Рис. 30. Поляков Владислав переможець у фестивалі «Future of Ukraine 2019», в Міжнародній конференції AWADE -2018 (Нанкінський університет аеронавтики та астронавтики (NUAA))

Започатковано добру традицію кожного навчального року відвідування студентами фракультету літакобудування Державного підприємства «Антонов», відвідування щорічного фестивалю авіації KharkivABIAfest 2019. 


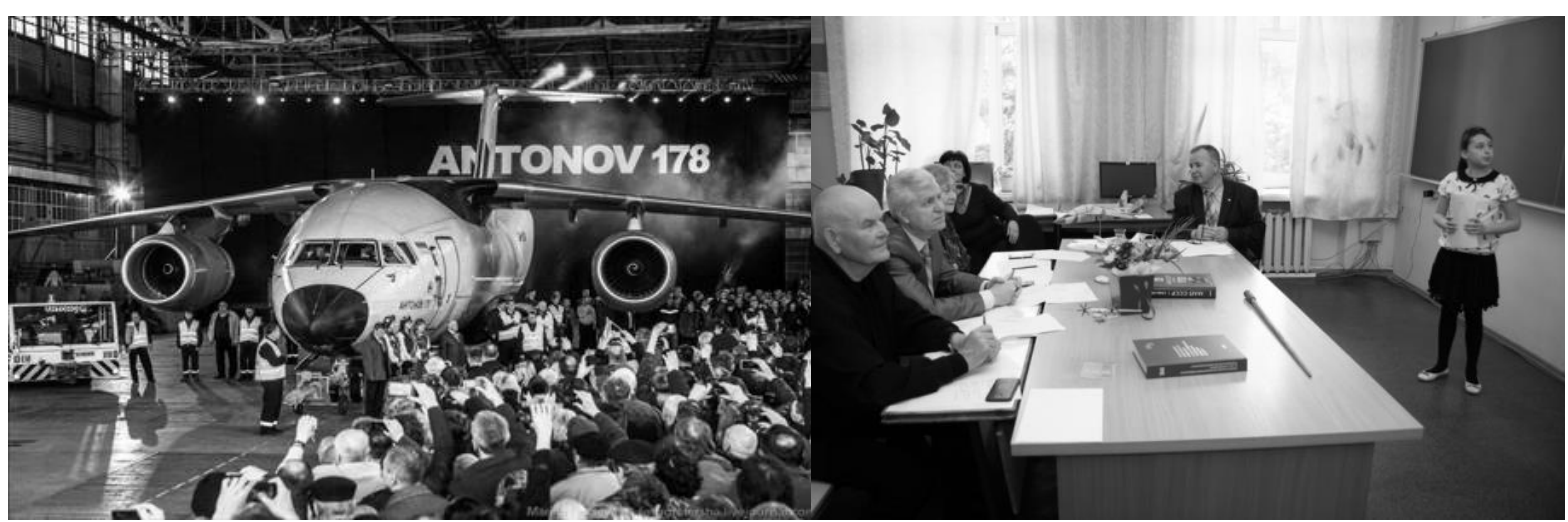

Рис. 31. Екскурсія на ДП «Антонов» (презентація Ан-178)

Рис. 32. XX науково-практична конференція учнівської молоді “Гагарінські читання"- 2019

На кафедрі організовано навчання іноземних студентів і стажування іноземних фрахівців.

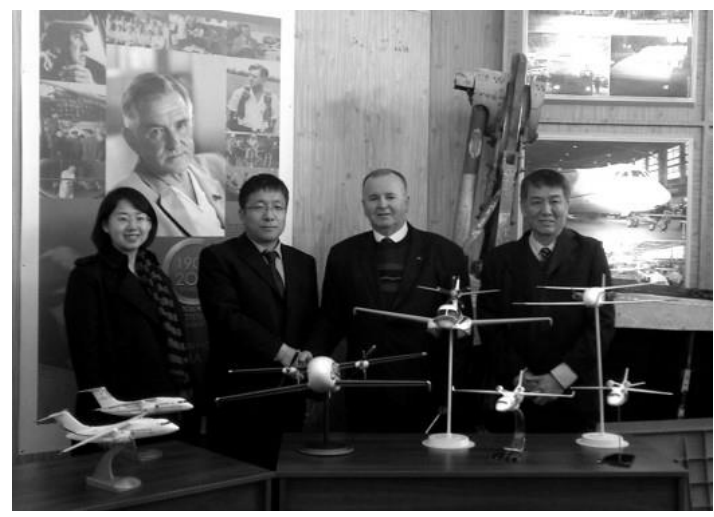

Рис. 33. Делегація фрахівців з Китаю

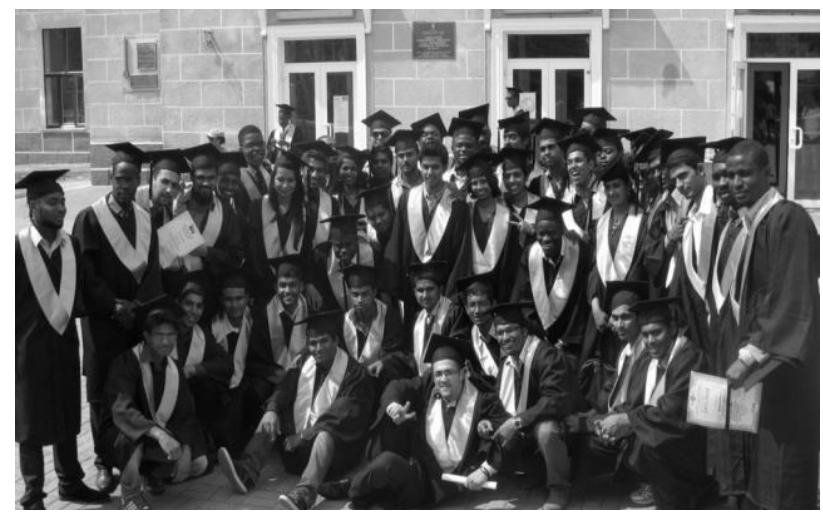

Рис. 32. Іноземні студенти - випускники

Сьогодні кафредра випускає бакалаврів і магістрів за такими спеціальностями:

- 134 «Авіаційна і ракетно-космічна техніка» (освітні програми «Літаки і вертольоти» та "Комп'ютерно-інтегроване проектування і конструювання авіаційної техніки"),

- 272 «Авіаційний транспорт» (освітня програма «Технічне обслуговування та ремонт повітряних суден і авіаційних двигунів»).

Наукова школа має в розпорядженні матеріальну базу: лабораторію конструкції літаків ім. Генерального конструктора О. К. Антонова; лабораторію конструкції вертольотів та обслуговування повітряних суден; науково-дослідну проблемну лабораторію ресурсу авіаційних конструкцій та лабораторію силових устаткувань; комп'ютерний клас ім. Генерального конструктора П. В. Балабуєва; навчальний центр CAD/CAM/CAE.

До складу наукової школи «Проектування і конструювання ефективної високоресурсної авіаційної техніки» в 2019 році входять висококваліфріковані фрахівці: 6 докторів наук - О. Г. Гребеніков, А. К. М'ялиця, В. І. Рябков, І. В. Малков, С. А. Бичков, С. В. Філіпковський; 12 кандидатів наук - В. М. Андрющенко, О. А. Бабушкін, А. М. Гуменний, Л. В. Капітанова, В. Г. Кубата, С. І. 
Овчаренко, М. М Орловський, А. В. Приймак, С. В. Трубаєв, М. М. Федотов, Т. П. Цепляєва, Є. Т. Василевський, А. В. Андреєв; доценти - В. А.Урбанович, М. С. Топал, старші викладачі - О. А. Сердюков, А. С. Чумак, Р. Ю. Цуканов; асистенти - Л. Ю. Буйвал, О. О. Соболєв.

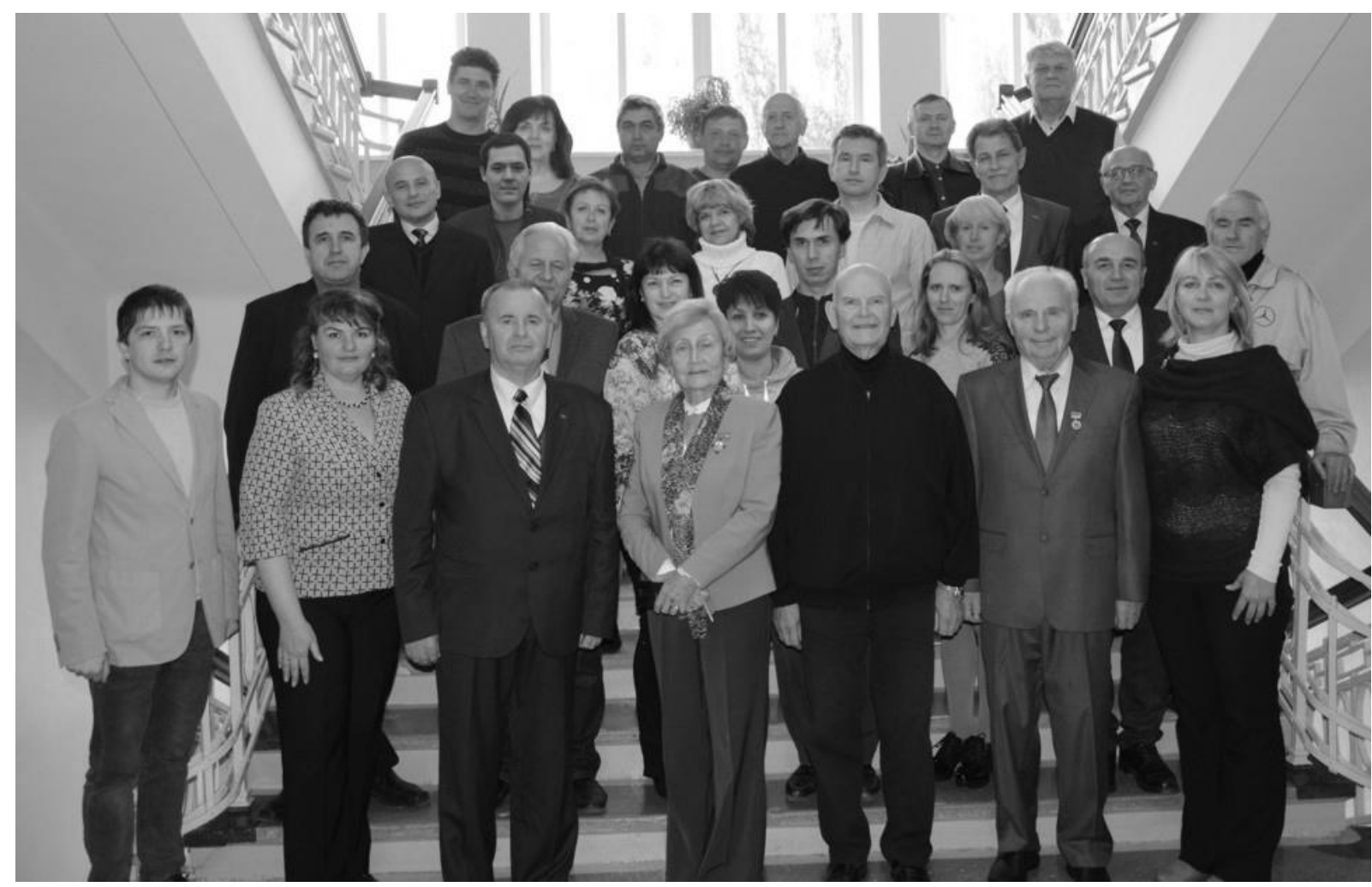

Рис. 34. Колектив кафедри 103

Колектив кафедри сподівається на гідну зміну в особі наших аспірантів: Д. С. Конишева, Д. Ю. Жирякова, В. С. Долгих, А. М. Івасенка.

Кафедра пишається своїми випускниками, серед яких $є$ Герої Соціалістичної Праці, Герої України, директор НДІ, шість головних конструкторів, багато головних інженерів, директори заводів, шість лауреатів Ленінської премії СРСР, лауреати премії Ради Міністрів СРСР, вісім лауреатів Державної премії України, 20 докторів наук, багато кандидатів наук та інших видатних наукових і адміністративних працівників. Вони працювали і працюють у проектних і наукових організаціях авіаційної промисловості України та за її межами.

Спеціалісти науково-освітньої школи кафедри сумісно співпрацюють 3 фрахівцями наукових шкіл XAI, авіаційних університетів і підприємств України, країн СНД і наукових зарубіжних центрів. Значний внесок у розвиток наукових шкіл зробило багато керівників підприємств авіаційної промисловості України.

Діяльність кафедри відповідає основним критеріям і вимогам положень про наукову школу. Школа має всі необхідні умови для розвитку.

Результати наукових досліджень науково-освітньої школи «Проектування і конструювання ефективної високоресурсної авіаційної техніки» впроваджені на авіаційних підприємствах України та стран СНГ.

На основі новітніх досягнень у галузі проектування і технології виробництва авіаційної техніки фахівці авіаційних підприємств України створили літаки Ан-70, 
Ан-74ТК-300, Ан-140, Ан-148, Ан-132, Ан-158, Ан-74ТК-200, Ан-124. В створення цих літаків значний вклад внесли співробітники кафедри та наші випускники. I нині ведуться роботи, спрямовані на створення нових модифікацій літаків.

Діяльність кафедри відповідає основним критеріям і вимогам положень про наукову школу.

\section{Список літератури}

1. Набатов, А.С. Крылья ХАИ [Текст] / А.С. Набатов, А.Г. Гребеников. Х.:,Нац. аэрокосм. ун-т «ХАИ», 2005.

2. Наукова школа XAI «Проектування і конструювання ефективної високоресурсної авіаційної техніки». Частина I (1930-1940рр.) /74, 201655 УДК 001.89:629.73.01 Т. П. Цепляєва, І. В. Каламбет, Т. М. Середа Наукова школа XAI «Проектування і конструювання ефрективної високоресурсної авіаційної техніки». Частина I (1930-1940рр.) Національний аерокосмічний університет ім. М. Є. Жуковського «Харківський авіаційний інститут»

3. Захарченко В. Д. Антонов (Серия: Жизнь замечательных людей).Москва: Молодая гвардия. 1996

4. Золотий фонд нації. Українці: творчість, інновації, інвестиції/ Упорядник В.В. Болгов. - К: Українська конфедерація журналістів 3-80 2019.

5. Національний аерокосмічний університет ім.. М.Є. Жуковського «Харківського авіаційний інститут»/ ред..кол.: В.С. Кривцов, Я.С. Карпов, В.Ф. Деменко та ін. - Харків: Нац. аерокосм. ун-т «Харк. авіац. ін-т», 2005.

6. Енциклопедія сучасної України / Електроний варіант: http://esu.com.ua/

7. Профрессор Лев Александрович Малашенко [Текст] : биобиблиогр. указ. / Харьк. авиац. ин-т; [сост.: И. В. Олейник, В. С. Гресь ; ред. Н. М. Ткаченко]. Харьков: ХАИ, 2013.

8. Профессор Александр Григорьевич Гребеников : к 70-летию со дня рождения : библиогр. указ. / сост.: И. В. Олейник, А. М. Гуменный, В. С. Гресь, И. П. Бега ; под общ. ред. Н. М. Ткаченко ; вступ. ст. Т. П. Цепляевой. - Х. : ХАИ, 2011.

9. Савин В. С. Авиация в Украине : очерки истории / В. С. Савин. -Х. : Основа, 1995.

10. Научное наследие профрессора И.Г.Немана (1903-1952) : предисл. редкол. журн. // Авиационно-космическая техника и технология. -2005 . - № 6 (22).-C. 94.

11. Набатов, А. С.Крылья ХАИ. 1930-2005 : очерки истории / А. С. Набатов, А.Г. Гребеников. -Х., 2005.

\section{References}

1. Nabatov, A.S. Krylya HAI [Tekst] / A.S. Nabatov, A.G. Grebenikov. H.:,Nac. aerokosm. un-t «HAl», 2005.

2. Naukova shkola HAl «Proektuvannya i konstruyuvannya efektivnoyi visokoresursnoyi aviacijnoyi tehniki». Chastina I (1930-1940 rr.) /74, 201655 UDK 001.89:629.73.01 T. P. Ceplyayeva, I. V. Kalambet, T. M. Sereda Naukova shkola HAl «Proektuvannya i konstruyuvannya efektivnoyi visokoresursnoyi aviacijnoyi tehniki». Chastina I (1930-1940 rr.) Nacionalnij aerokosmichnij universitet «HAI»

3. Zaharchenko V. D. Antonov (Seriya: Zhizn zamechatelnyh lyudej).- Moskva: Molodaya gvardiya. 1996 
4. Zolotij fond naciyi. Ukrayinci: tvorchist, innovaciyi, investiciyi/ Uporyadnik V.V. Bolgov. - K: Ukrayinska konfederaciya zhurnalistiv 3-80 2019.

5. Nacionalnij aerokosmichnij universitet «HAI»/ red..kol.: V.S. Krivcov, Ya.S. Karpov, V.F. Demenko ta in. - Harkiv: Nac. aerokosm. un-t «Hark. aviac. in-t», 2005.

6. Enciklopediya suchasnoyi Ukrayini / Elektronij variant: http://esu.com.ua/

7. Professor Lev Aleksandrovich Malashenko [Tekst] : biobibliogr. ukaz. I Hark. aviac. in-t; [sost.: I. V. Olejnik, V. S. Gres ; red. N. M. Tkachenko]. - Harkov: HAl, 2013.

8. Professor Aleksandr Grigorevich Grebenikov : k 70-letiyu so dnya rozhdeniya : bibliogr. ukaz. / sost.: I. V. Olejnik, A. M. Gumennyj, V. S. Gres, I. P. Bega ; pod obsh. red. N. M. Tkachenko ; vstup. st. T. P. Ceplyaevoj. - H. : HAI, 2011.

9. Savin V. S. Aviaciya v Ukraine : ocherki istorii / V. S. Savin. -H. : Osnova, 1995.

10. Nauchnoe nasledie professora I.G.Nemana (1903-1952) : predisl. redkol. zhurn. // Aviacionno-kosmicheskaya tehnika i tehnologiya. -2005. - No 6 (22).-S. 94.

11. Nabatov, A. S.Krylya HAI. 1930-2005 : ocherki istorii / A. S. Nabatov, A.G. Grebenikov. -H., 2005.

\section{Відомості про авторів:}

Гребеніков Олександр Григорович - д-р техн. наук, професор, завідуючий кафедри проектування літаків і вертольотів Національного аерокосмічного університету ім. М.Є. Жуковського «XАl», м. Харків, Україна.

Цепляєва Тамара Павлівна - канд. техн. наук, доцент, профресор кафедри проектування літаків і вертольотів Національного аерокосмічного університету ім. М.Є. Жуковського «XАІ», м. Харків, Україна.

Мельніченко Вікторія Ростиславівна - інженер I категорії кафедри проектування літаків і вертольотів Національного аерокосмічного університету ім. М.Є. Жуковського «XAI», м. Харків, Україна.

\section{About the Authors}

Alexander Grebenikov - Doctor of Engineering Science, professor, Head of Department of Airplanes and Helicopters Design, National Aerospace University "KhAl", Kharkiv, Ukraine. ORCID: 0000-0002-1509-0665

Tseplyaeva Tamara Pavlivna - Candidate in Tech. Sciences, Associate Professor, Professor of Aircraft and Helicopter Design Department No. 103, National Aerospace University "KhAl", Kharkiv, Ukraine.

Melnichenko Viktoriya Rostislavivna - 1st category engineer, department 103, National Aerospace University "KhAl", Kharkiv, Ukraine. 